\title{
KORELASI MOTIVASI BELAJAR DENGAN PRESTASI BELAJAR IPS KELAS VI DI SEKOLAH DASAR NEGERI
}

\author{
${ }^{1)}$ Moefty Mahendra, ${ }^{2)}$ Setiyani \\ ${ }^{1)}$ Pendidikan Guru Sekolah Dasar, Univet Bantara Sukoharjo \\ Email: mahendra_moefty@gmail.co.id \\ ${ }^{2)}$ Pendidikan Guru Sekolah Dasar, Univet Bantara Sukoharjo \\ Email: setiyani@yahoo.co.id
}

\begin{abstract}
Abstrak
Tujuan penelitian ini adalah untuk mengetahui korelasi antara motivasi belajar dengan prestasi belajar ilmu pengetahuan sosial pada siswa kelas VI Semester II Sekolah Dasar Negeri Bugel 02 Kecamatan Polokarto Kabupaten Sukoharjo Tahun Pelajaran 2017/2018. Populasi dalam penelitian ini adalah siswa kelas VI Sekolah Dasar Negeri Bugel 02 Kecamatan Polokarto Kabupaten Sukoharjo yang berjumlah 21 siawa, dan sekaligus sebagai sampel penelitian. Metode pengumpulan data menggunakan angket dan dokumentasi. Metode analisis data yang digunakan adalah dengan statistik korelasi product moment. Hasil penelitian ini menunjukkan bahwa, ada korelasi positif antara motivasi belajar dengan prestasi belajar hipotesis antara X dengan $\mathrm{Y}$ diketahui nilai rhit > rtabel dengan nilai $0,874>0.602$ dan taraf signifikan kurang dari 0.05 , maka dapat disimpulkan bahwa adanya korelasi signifikan antara motivasi belajar dengan nilai prestasi belajar Ilmu Pengetahuan Sosial. Namun masih banyak variabel-variabel lain yang dapat mempengaruhi nilai prestasi belajar.
\end{abstract}

Kata kunci: Motivasi Belajar, Prestasi Belajar, IPS

\begin{abstract}
The purpose of this study was to determine the correlation between learning motivation and social science learning achievement in class VI Semester II Bugel 02 Elementary School in Polokarto District Sukoharjo District 2017/2018 Academic Year. The population in this study were class VI students of Bugel 02 State Elementary School, Polokarto District, Sukoharjo Regency, which amounted to 21 students, and at the same time as research samples. Methods of data collection using questionnaires and documentation. The data analysis method used is product moment correlation statistics. The results of this study indicate that, there is a positive correlation between learning motivation and learning achievement hypotheses between $\mathrm{X}$ and $\mathrm{Y}$ known rhit value> rtable with a value of $0.874>0.602$ and a significance level of less than 0.05 , it can be concluded that there is a significant correlation between learning motivation and
\end{abstract}


achievement scores study Social Sciences. But there are still many other variables that can affect the value of learning achievement.

Keywords: Learning Motivation, Learning Achievement, IPS

\section{PENDAHULUAN}

Belajar merupakan suatu proses untuk memperoleh hasil yang dapat berupa perubahan tingkah laku yang dihasilkan setelah melakukan kegiatan belajar dan berinteraksi dengan lingkungan. Perubahan yang terjadi dalam proses belajar dapat dipahami sebagai tahapan perubahan seluruh tingkah laku individu yang relatif menetap sebagai hasil pengalaman dan interaksi dengan lingkungan yang melibatkan proses kognitif (Syah, 2011).

Belajar di dalamnya terdapat suatu proses yang dikenal sebagai proses pembelajaran. Proses pembelajaran merupakan komponen pendidikan yang penting dalam meningkatkan kualitas pendidikan karena pada proses pembelajaran terdapat interaksi antara guru dan siswa. Siswa dikatakan berhasil dalam proses pendidikan, apabila dapat menyelesaikan pendidikan tepat pada waktunya dengan prestasi yang baik. Salah satu faktor internal yang mempengaruhi keberhasilan siswa adalah motivasi untuk belajar. Motivasi merupakan salah satu hal yang mendukung dalam pendidikan dan mendasari siswa dalam melaksanakan belajarnya. Motivasi sebagai daya penggerak siswa yang telah menjadi aktif, mendorong siswa terutama bila kebutuhan untuk mencapai tujuan sangat dirasakan/mendesak (Sardiman, 2001).

Menurut Uno (2007) menjelaskan motivasi merupakan kekuatan dari dalam maupun dari luar yang mendorong seseorang untuk mencapai tujuan tertentu yang telah ditetapkan sebelumnya. Motivasi tiap orang berbeda-beda karena pengaruh beberapa faktor, diantaranya: perbedaan fisiologis, perbedaan rasa aman, perbedaan kasih sayang atau afeksi, perbedaan harga diri dan perbedaan aktualisasi diri. Kekurangan atau ketiadaan motivasi baik yang bersifat internal maupun eksternal akan menyebabkan kurang bersemangatnya siswa dalam melakukan proses pembelajaran. Faktor intern yaitu dari dalam diri siswa yang meliputi: kecerdasan, bakat, minat, motivasi diri, disiplin diri dan 
kemandirian. Sedangkan faktor ekstern adalah dari luar siswa yang meliputi: lingkungan alam, kondisi sosial, ekonomi, lingkungan sekolah, guru, kurikulum dan sebagainya.

Motivasi dan belajar merupakan dua hal yang saling mempengaruhi. Motivasi belajar adalah dorongan internal dan eksternal pada siswa yang sedang belajar untuk mengadakan perubahan tingkah laku. Pada umumnya dengan beberapa indikator atau unsur yang mendukung. Indikator tersebut yaitu adanya hasrat dan keinginan berhasil, adanya dorongan dan kebutuhan dalam belajar, adanya harapan dan cita-cita masa depan, adanya penghargaan dalam belajar, adanya kegiatan yang menarik dalam belajar, adanya lingkungan belajar yang kondusif sehingga memungkinkan siswa dapat belajar dengan baik (Uno, 2007).

Motivasi belajar dimiliki oleh siswa yang menyadari bahwa belajar merupakan suatu kebutuhan sehingga ia akan berusaha sebaik-baiknya untuk mendapatkan hasil yang maksimal. Hasil belajar siswa setelah mengikuti proses pembelajaran disebut dengan prestasi belajar. Prestasi belajar merupakan penampakan dari hasil belajar, setiap orang melakukan suatu aktifitas untuk mencapai tujuan tertentu, pada akhirnya mereka ingin mengetahui hasil yang dicapai dalam hal ini kegiatan belajar, yang salah satu bentuknya yaitu prestasi belajar. Bagi siswa disekolah prestasi merupakan faktor penting bagi siswa untuk mengetahui sejauh mana ia telah berhasil menguasai materi yang dipelajarinya. Prestasi belajar digunakan sebagai indikator penguasaan kompetensi siswa terhadap materi ajar. Prestasi tinggi dapat dicapai dengan ketekunan belajar yang terbentuk dari adanya motivasi belajar yang akan mengarahkan perilaku siswa pada pencapaian prestasi belajar yang maksimal.

Faktor lain yang menentukan prestasi belajar seseorang adalah kesiapan belajar. Sebagai siswa tidak dapat dilepaskan dari aktivitas belajar, dan untuk menunjang hal tersebut diperlukan kesiapan belajar yaitu kondisi awal suatu kegiatan belajar yang membuatnya siap untuk memberi respon atau jawaban yang ada pada diri siswa dalam mencapai tujuan pengajaran tertentu (Djamarah dan Aswan, 2006). 


\section{METODE PENELITIAN}

Penelitian ini menggunakan desain penelitian korelasional yaitu mengungkapkan masalah penelitian dengan cara membuktikan hubungan antara dua variabel atau lebih (Nawawi dan Martini, 1994 : 108). Sedangkan jenis penelitian yang digunakan adalah observasional analitik dengan pendekatan cross sectional. Variabel yang diteliti hanya diukur satu kali pengukuran saja dalam waktu tertentu (Soekidjo, 2002).

Penelitian ini dilaksanakan di Sekolah Dasar Negeri Bugel 02 di Dukuh Brajan RT 01/RW 02 Desa Bugel Kecamatan Polokarto Kabupaten Sukoharjo. Penelitian ini dilaksanakan pada bulan Maret sampai dengan Mei semester genap tahun pelajaran 2017/2018. populasi dalam penelitian ini adalah seluruh siswa Kelas VI SD Negeri Bugel 02 Kecamatan Polokarto Kabupaten Sukoharjo Tahun Pelajaran 2017/2018 yang berjumlah 21 siswa. Dikarenakan populasi hanya berjumlah 21 siswa, maka penelitian ini menggunakan penelitian populasi.

Variabel bebas pada penelitian ini adalah motivasi belajar. Motivasi belajar yang dimaksud dalam penelitian ini adalah motivasi belajar yang diberikan guru terhadap siswa untuk mencapai hasil yang memuaskan. Sedangkan variabel terikat adalah prestasi belajar IPS. Prestasi belajar yang dimaksud dalam penelitian ini adalah hasil akhir ujian semester genap tahun pelajaran 2017/2018 yang merupakan bukti keberhasilan setelah proses belajar.

Teknik pengumpulan data melalui metode angket dan dokumentasi. Metode angket digunakan untuk memperoleh data tentang motivasi belajar (X) dengan prestasi belajar (Y) dengan cara memberi soal-soal angket kepada responden sebagai hasil dari pengukuran tersebut diperoleh data yang berupa skor.

Angket diujicobakan terhadap sejumlah responden di SD Negeri Bugel 02 Kecamatan Polokarto Kabupaten Sukoharjo berjumlah 21 siswa kelas VI, Angket diujicobakan lalu diuji validitas maupun reliabilitasnya. Validitas dilakukan melalui metode analisis produt moment, sedangkan reliabilitas melalui metode Spearman Brown.

Analisis data dilakukan dengan statistik diharapkan dapat menyediakan dasar-dasar yang lebih dapat dipertanggung jawabkan dalam upaya untuk 
mengetahui ada tidaknya korelasi motivasi belajar dan prestasi belajar siswa kelas VI semester II Sekolah Dasar Negeri Bugel 02 Kec. Polokarto Kab. Sukoharjo Tahun Pelajaran 2017/2018. Analisis data yang digunakan pada penelitian ini adalah uji korelasi dan uji signifikansi.

\section{HASIL PENELITIAN DAN PEMBAHASAN}

\section{a. Hasil Penelitian}

1) Penyebaran Data Motivasi Belajar (X)

Pada perolehan data motivasi belajar, dari 21 sampel penelitian, sekor tertinggi mencapai 79 sedangkan sekor terendah 47 sehingga penyebaranya dapat dilihat sebagai berikut :

Tabel1. Distribusi Frekuensi Data Motivasi Belajar

\begin{tabular}{cc}
\hline Kelas Interval & Frekuensi \\
\hline $46-50$ & 2 \\
$51-55$ & 2 \\
$56-60$ & 1 \\
$61-65$ & 5 \\
$66-70$ & 6 \\
$71-75$ & 4 \\
$76-80$ & 1 \\
\hline
\end{tabular}

Dari distribusi frekuensi data motivasi belajar dapat digambarkan dengan grafik histogram sebagai berikut :

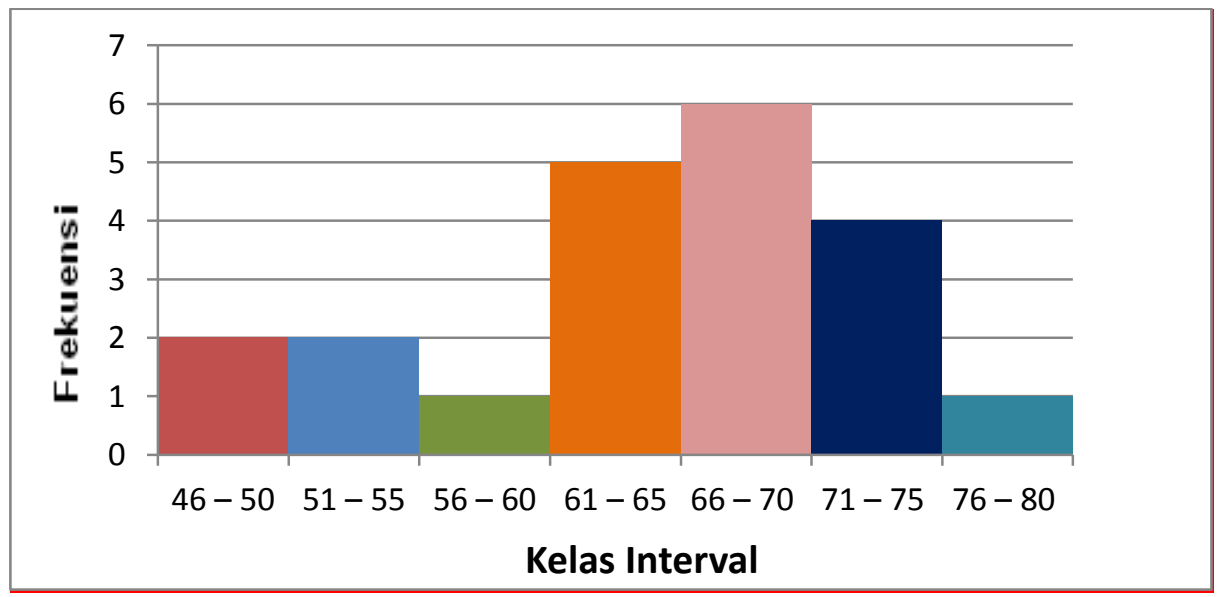

Gambar 1. Histogram Distribusi Frekuensi Data Motivasi Belajar 
2) Penyebaran data untuk variabel Prestasi Belajar IPS (Y)

Pada dokumen data tentang variabel Y, yaitu Prestasi Belajar Ilmu Pengetahuan Sosial, nilai tertinggi 90 dan terendah 55. Adapun distribusi frekuensi sebagai berikut:

Tabel 2. Distribusi Frekuensi Data Prestasi Belajar IPS (Y)

\begin{tabular}{cc}
\hline Kelas Interval & Frekuensi \\
\hline $55-60$ & 2 \\
$61-65$ & 1 \\
$66-70$ & 4 \\
$71-75$ & 4 \\
$76-80$ & 3 \\
$81-85$ & 5 \\
$86-90$ & 2 \\
\hline
\end{tabular}

Dari data Frekuensi Prestasi Belajar Ilmu Pengetahuan Sosial dapat digambarkan dengan grafik histogram sebagai berikut :

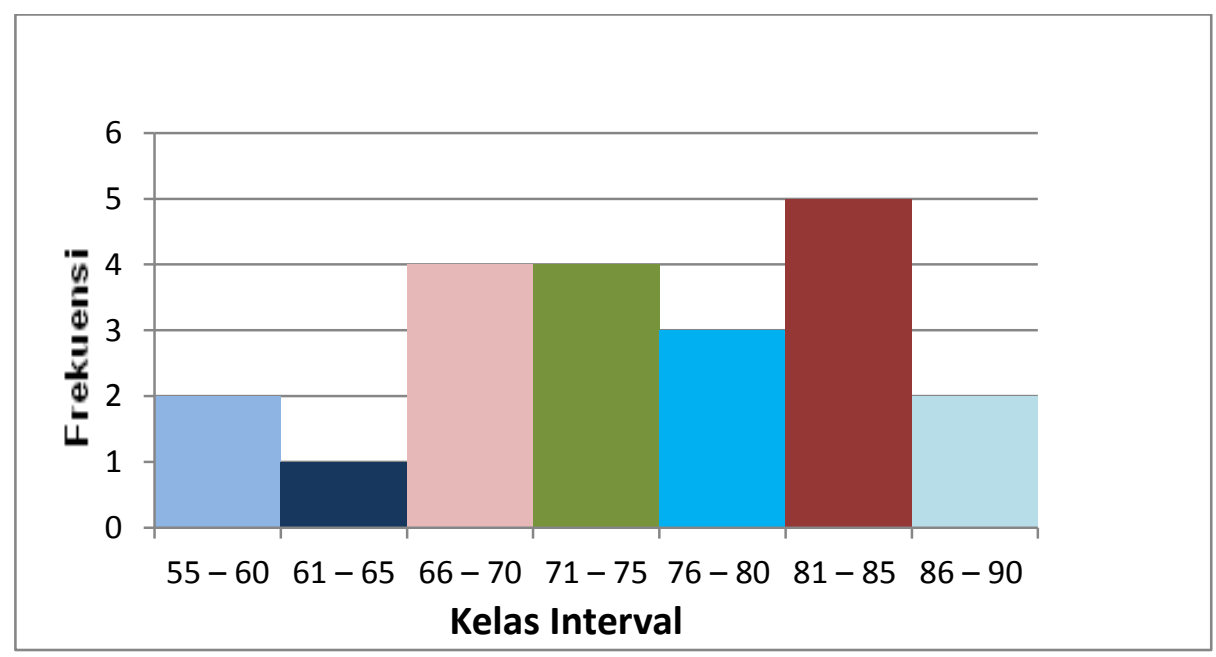

Gambar 3. Histogram Distribusi Frekuensi Data Prestasi Belajar IPS

\section{b. Analisis Data}

\section{1) Hasil Uji Prasyarat}

Uji normalitas sebagai uji prasyarat dilakukan untuk mengetahui apakah data dari beberapa variabel berdistribusi normal, jika uji normalitas dengan menggunakan kalmogorov-smirnov, berdistribusi normal maka bisa melanjutkan ke uji hipotesis. Pada hasil uji normalitas untuk variabel 
motivasi belajar $(\mathrm{X})$, diperoleh hasil berdistribusi normal yaitu dengan harga $\lambda^{2}=0,243$. Pada hasil uji normalitas untuk variabel Prestasi Belajar (Y) diperoleh hasil berdistribusi normal yaitu dengan harga $\lambda=0,104$.

Uji linieritas merupakan uji prasyarat untuk mengetahui hubungan linier antara variabel bebas dengan variabel terikat. Uji linieritas antara variabel $\mathrm{X}$ dan $\mathrm{Y}$, yaitu variabel motivasi belajar dengan prestasi belajar ilmu pengetahuan sosial. Dari hasil uji nilai signifikan sebesar 0,000 artinya signifikasi kurang dari 0,05 maka dapat disimpulkan bahwa antara variabel motivasi belajar dengan prestasi belajar ilmu pengetahuan sosial terdapat hubungan yang linier.

\section{2) Uji Hipotesis}

Oleh karena dari data 2 variabel penelitian telah dilakukan uji prasyarat yaitu tentang uji normalitas dan uji linieritas, dan hasilnya memenuhi syarat untuk dilanjutkan ke uji hipotesis, maka dalam uji hipotesis diperoleh hasil Hipotesis = Ada hubungan yang positif antara motivasi belajar dengan prestasi belajar ilmu pengetahuan sosial siswa kelas VI semester II Sekolah Dasar Negeri Bugel 02 Kecamatan Polokarto Kabupaten Sukoharjo Tahun pelajaran 2017/2018.Untuk menguji hipotesis tersebut, berdasarkan perhitungan analisis Korelasi Product Moment dari Pearson diperoleh harga korelasi $=0,874$

\section{b. Pembahasan}

Berdasarkan penelitian yang dilakukan data prestasi belajar Ilmu Pengetahuan Sosial (IPS) menggunakan instrumen dokumen. Dokumen ini diambil dari nilai hasil akhir mata pelajaran ilmu pengetahuan sosial siswa kelas VI semester II Sekolah Dasar Negeri Bugel 02 Kecamatan Polokarto Kabupaten Sukoharjo Tahun pelajaran 2017/2018, dengan jumlah responden 21 orang. Dari perhitungan antara variabel motivasi belajar dengan variabel prestasi belajar ada hubunagn positif, yaitu dengan nilai korelasi person 0,874 dan taraf signifikan 0.001. Hasil hipotesis dikatakan adanya korelasi dengan hasil konsultasi nilai $\mathbf{r}_{\text {hit }}>$ $\mathrm{r}_{\text {tabel }}$ dengan nilai $0.874>0.602$ dan taraf signifikan yang kurang dari 0.05 . 
Penelitian ini membuktikan bahwa semakin tinggi nilai motivasi belajar maka semakin tinggi pula nilai prestasi belajar ilmu pengetahuan sosial. Motivasi belajar diambil sebagai faktor lain karena motivasi belajar merupakan dorongan yang memegang peranan penting dalam pencapaian prestasi belajar (Sugihartono dkk, 2011:78). Berdasarkan hasil yang diperoleh pada uji coba angket motivasi belajar dari 20 item hanya 18 item angket yang valid. Untuk uji coba angket di lakukan pada 30 responden dengan korelasi tabel sebesar 0.361. Hasil perhitungan tiap item angket dikonsultasikan dengan korelasi tabel dan hasil yang tidak valid adalah nomor item 7 dan nomor item 15 dengan hasil korelasi -0.88 dan -0.343. Setelah dilakukan uji validitas data item angket di ujikan dengan uji reliabilitas instrumen, hasil dengan jumlah item 20 menggunakan rumus Alpha Cronbach adalah 0.719. Dan pada jumlah item setelah adanya pengurangan yang tidak valid diketahui reliabilitas item sebesar 0.793 dengan jumlah item 18 dan terjadi peningkatan hasil reabilitas setelah adanya pengurangan item yang tidak valid. Setelah angket diuji cobakan ke responden diluar responden penelitian diketahui bahwa angket sudah valid dan dapat digunakan sebagai instrumen penelitian. Dari perhitungan antara motivasi belajar dengan nilai prestasi belajar diketahui adanya korelasi antar kedua variabel yaitu sebesar 0.733 dan taraf signifikan 0.01 maka hasil penelitian sesuai dengan pendapat oleh suyahman (2006: 113) mengenai motivasi belajar yang merupakan salah satu faktor yang mempengaruhi suatu keberhasilan.

\section{SIMPULAN}

Dari hasil uji analisis data, maka pada penelitian ini dapat disimpulkan sebagai berikut "Ada korelasi yang positif antara motivasi belajar dengan prestasi belajar ilmu pengetahuan sosial siswa kelas VI semester II Sekolah Dasar Negeri Bugel 02 Kecamatan Polokarto Kabupaten Sukoharjo Tahun pelajaran 2017/2018. Untuk menguji hipotesis tersebut, berdasarkan perhitungan analisis Korelasi Product Moment dari Pearson diperoleh harga korelasi = 0,874". 
Berdasarkan hasil penelitian yang telah teruji kebenarannya bahwa motivasi belajar berhubungan dengan prestasi belajar ilmu pengetahuan sosial siswa kelas VI semester II Sekolah Dasar Negeri Bugel 02 Kecamatan Polokarto Kabupaten Sukoharjo Tahun pelajaran 2017/2018. Dari hasil penelitian mengenai variabel motivasi belajar dengan variabel nilai prestasi belajar ilmu pengetahuan sosial, ternyata menunjukkan hubungan yang signifikan. Variabel motivasi belajar memberikan kontribusi sebesar 38.1\%. Indikator variabel prestasi belajar ditentukan dari hasil akhir nilai pada mata pelajaran ilmu pengetahuan sosial. Siswa perlu mengembangkan motivasi belajar yang tinggi, sehingga prestasi belajar ilmu pengetahuan sosial akan meningkat.

Berdasarkan penelitian di atas dapat digunakan sebagai dasar pengembangan selanjutnya, kerena masih banyak variabel - variabel lain yang berkaitan dengan prestasi belajar.

\section{DAFTAR PUSTAKA}

Abdurrahman, M. 1993. Pendidikan Bagi Anak Berkesulitan Belajar. Cetakan Pertama. Jakarta: PT. Rineka Cipta dan Departemen Pendidikan dan Kebudayaan.

Bahri, Syaiful Djamarah. 2011. Psikologi Belajar. Jakarta: Rineka Cipta.

Djamarah, Syaiful Bahri dan aswan Zain. 2010. Strategi Belajar Mengajar. Jakarta: Rineka Cipta.

Gagne, Robert M and Leslie J. Briggs, 1978. Principles of Instructional Design. $2^{\text {nd }} E d$, New York : Holt Rinehart and Winstons.

Hamdani, 2011.Strategi Belajar Mengajar. Bandung: CV Pustaka Setia.

Ngalim Purwanto. 1997. Prinsip-prinsip dan Teknik Evaluasi Pengajaran. Bandung: PT Remaja Rosdakarya

Oemar Hamalik. 1992. Psikologi Belajar dan Mengajar. Bandung: Sinar Baru Aglesindo.

Poerwadarminta, W.J.S. 2007. Kamus Umum Bahasa Indonesia. Jakarta: Balai Pustaka. 
Purwanto, M. Ng. 2007. Psikologi Pendidikan. Bandung : PT Remaja Rosdakarya.

Rifa'i, Ahmad dan Catharina Tri Anni. 2011. Psikologi Pendidikan. Semarang : Universitas Negeri Semarang Press.

Sani, Ridwan Abdullah. 2013. Inovasi Pembelajaran. Jakarta: PT. Bumi aksara.

Sardirman. 2001. Interaksi dan Motivasi Belajar Mengajar. Jakarta: PT Raja Grafindo Persada.

Slameto.2003. Belajar dan Faktor-Faktor yang Mempengaruhi. Jakarta : Rineka Cipta.

Syah, Muhibbin. 1995. Psikologi Belajar. Jakarta: Raja Grafindo Persada.

Syah. 2011. Psikologi Belajar. Jakarta: Raja Grafindo Persada.

Sugihartono, dkk. 2011. Psikologi Pendidikan. Yogjakarta: UNY Press

Suyahman. 2006. Belajar dan Pembelajaran. Surakarta: Usaha Mandiri.

Suprijono. 2010. Cooperatif Learning. Yogyakarta: Pustaka Pelajar.

Uno, H. B. 2007. Teori Motivasi dan Pengukurannya. Jakarta : Bumi Aksara.

Tengker, V. S.G., dan Jenny M., 2007, Pengaruh Motivasi Karir Terhadap Minat Mahasiswa Akuntansi untuk Mengikuti Pendidikan Profesi Akuntansi (PPAk), skripsi, Manado.

Trianto. 2010. Model-model Pembelajaran Inovatif Berorientasi Kontruktivistik. Jakarta: Prestasi Pustaka.

Winataputra, Udin S. 2008. Teori Belajar dan Pembelajaran. Jakarta: Universitas Terbuka.

Winkel. 1986. Psikologi pengajaran. Yogyakarta: Media Abadi.

Zainal Arifin. 2012. Evaluasi Pembelajaran. Jakarta: Direktorat Pendidikan Tinggi Islam 